\title{
Application of titania based adsorbent for removal of acid, reactive and direct dyes from textile effluents
}

\author{
Monika Wawrzkiewicz ${ }^{1} \cdot$ Ewelina Polska-Adach $^{1} \cdot$ Zbigniew Hubicki $^{1}$
}

Received: 30 November 2018 / Revised: 28 January 2019 / Accepted: 10 February 2019 / Published online: 21 March 2019

(c) The Author(s) 2019

\begin{abstract}
In the present study, the titania based adsorbent (Adsorbsia As500) was used for removal of three textile dyes such as C.I. Acid Red 18, C.I. Reactive Blue 21 and C.I. Direct Yellow 50 from aqueous solutions. The dye sorption was investigated by the batch and column methods. The experimental data were analyzed by the Langmuir, Freundlich and Temkin models of adsorption. Adsorbsia As500 exhibited the highest affinity towards DY50 as the monolayer sorption capacity were equal to $109.71 \mathrm{mg} / \mathrm{g}$. The kinetic data obtained at different dyes concentrations were fitted to the pseudo-first order, pseudo-second order and Elovich equations. The dyes desorption experiments were investigated, too.
\end{abstract}

\section{Introduction}

The intensive development of civilization and the rapidly growing needs of society mean that the twenty-first century industry is developing rapidly in many fields. Thus each of them in an indirect or direct way deteriorates the environment conditions. One of the environmental components exposed to contamination is water. Liquid wastes from textile, paint, paper or leather industries constitute its pollution. In the textile industry, which is the largest recipient of dyes, there are formed very large amounts of highly coloured wastewaters of different chemical compositions depending on many factors, such as dyeing methods, type of coloured raw material (type of fabric), as well as type and amount of dyes. These wastewaters can contain not only dyes but also auxiliaries (salts, acids, alkalis, surfactants) and other specific impurities (fats, waxes, bleaches, dextrins) which are a heavy burden for them (Majewska-Nowak 1986; Anielak 2000; Solecka et al. 2005). Even very small amounts of dyes, up to several ppm are undesirable, as they affect the colour of water and disqualify it for home and technological purposes. A large number of dyes is not biodegradable which weakens the sunlight penetration into the water, and consequently, leads to inhibition of photosynthesis. In addition,

Monika Wawrzkiewicz

m.wawrzkiewicz@ poczta.umcs.lublin.pl

1 Department of Inorganic Chemistry, Faculty of Chemistry, Maria Curie-Sklodowska University, M. Curie-Sklodowska Sq. 2, 20-031 Lublin, Poland some dyes are mutagenic and carcinogenic for living organisms so their presence in water may have a negative effect on them (Derudi et al. 2007; Mo et al. 2008). For example, malachite green belonging to the triphenylmethane group of dyes has an adverse effect on the functioning of liver, reproductive system and kidneys. It also causes chromosomal damage and respiratory enzymes impairment (Srivastava et al. 2004). Moreover, Cha et al. (2001) have shown that this dye can contribute to the formation of tumours. Numerous reports on the negative impact of dyes on the environment have contributed to the creation of ETAD (Ecological and Toxic Association of Dyestuff and Pigment Producers) which deals with classification of hazardous dyes and dissemination of knowledge about their negative effects among manufacturers (Robinson et al. 2001). Based on the tests carried out by ETAD for 3000 commonly used dyes, it turned out that in 27 cases the $\mathrm{LC}_{50}$ (the median lethal dose) values reached the order of $0.05 \mathrm{mg} / \mathrm{L}$ (Salleh et al. 2011). High toxicity was found for C.I. Basic Violet $1\left(\mathrm{LC}_{50}=0.05 \mathrm{mg} / \mathrm{L}\right)$ and C.I. Basic Yellow 37 ( $\left.\mathrm{LC}_{50}=0.8 \mathrm{mg} / \mathrm{L}\right)$ (Holme 1984). Due to such serious environmental problems, the removal of the above-mentioned harmful substances has become an essential research topic.

Quite a large variety of dyes used in industry means that there is not one universal method of their removal from wastewaters. Technologies that combine physical, chemical and biological methods are considered the most effective, and their choice depends on many factors (such as type and concentration of the dye, chemical composition of the sewage, the presence of the additional impurities or costs of 
the process) (Chandrasekha and Pramad 2006). Adsorption is still the most common due to simple operation, low cost and, at the same time, high efficiency (Erdem et al. 2016). The sorbents that can be used in this process are: waste materials of plant origin (Ferraro 2007; Mittal et al. 2007; Namasivayam et al. 1998), activated carbon (Wang and Zhu 2007; Ruey-Shin et al. 2000; Pereira et al. 2003), chitosan and its composites (Momenzadeha et al. 2011) or anion exchange resins (Wawrzkiewicz et al. 2010; Wawrzkiewicz and Hubicki 2009). In order to improve the adsorption efficiency and the separation factor, it is necessary to search for and design new sorbents. Recently, mesoporous and microporous oxides as well as their mixtures have become a rather popular research area (Siwińska-Stefańska et al. 2012, 2017; Wawrzkiewicz et al. 2015a, b; Wiśniewska et al. 2014). Their morphological and microstructural properties as well as mechanical strength and non-toxicity make them desired adsorbents. Of some significance is the adsorbent consisting of aluminum and silicon oxide which was used for removal of malachite green (MG), rhodamine B (RB) and methylene blue (MB) from aqueous solutions (Khan et al. 2004). The amounts of dyes adsorbed by the oxide from the aqueous phase of the initial dyes concentrations from 5 to $20 \mathrm{mg} / \mathrm{L}$ were in the following range: $0.223-0.798 \mathrm{mg}$ MG/g, 0.196-0.674 mg RB/g and 0.274-0.839 mg MB/g. The removal percentage of these dyes ranges from 67.35 to 98.18 , therefore the authors considered it a relatively good material for removal of organic compounds, especially dyes (Khan et al. 2004). $\mathrm{Na}_{0.5} \mathrm{Li}_{0.5} \mathrm{CoO}_{2}$ was applied by Khorsavi and Eftekhar (2014) for methylene blue removal. The sorption capacity of $\mathrm{Na}_{0.5} \mathrm{Li}_{0.5} \mathrm{CoO}_{2}$ was found to be $502.1 \mathrm{mg} / \mathrm{g}$. In addition, after a short period of time $-10 \mathrm{~min}$, up to $92 \%$ of the dye was efficiently removed (Khorsavi and Eftekhar 2014). Another example of effective adsorbent based on iron and aluminum oxides $\left(\mathrm{Fe}_{2} \mathrm{O}_{3}-\mathrm{Al}_{2} \mathrm{O}_{3}\right)$ applied for Congo Red (CR) retention was described by Mahapatra et al. (2013a, b). Moreover, the adsorption equilibrium (498 mg CR/g) was achieved in a very short period $(\mathrm{t}=15 \mathrm{~min}$.). The nanocomposite used in the study showed $100 \%$ removability of Congo Red. Not only Andrzejewska et al (2004) and Przybylska et al. (2012) but also Jafari et al. 2015, 2016a) proved that modification of the surface of adsorbents based on titanium and/or silicon oxides has a positive effect on the improvement of their sorption capacity relative to dyes of various types. It is also worth mentioning that titanium oxide based materials can be used in the photocatalytic decomposition of organic compounds including dyes (Jafari et al. 2016b, Mohammadi and Karim 2017; Siwińska-Stefańska et al. 2018). What is more, iron and aluminum mixed oxide has also found practical applications in removal of heavy metal ions $\left(\mathrm{Cu}^{2+}, \mathrm{Pb}^{2+}, \mathrm{Ni}^{2+}, \mathrm{Hg}^{2+}\right.$ and $\left.\mathrm{Cr}^{6+}\right)$ from aqueous solutions (Mahapatra et al. 2013a, b; Mikhaylov et al. 2016; Wołowicz et al. 2018).
This work is aimed at the investigating sorption properties of titania based material (Adsorbsia As500) for removal of textile dyes of different types. Adsorbsia As500 is designed for arsenic, lead and other heavy metals removal of nonregenerative applications.

For the first time in literature an attempt was made to use As500 for removing textile dyes of various types, which under anaerobic conditions may be degraded to toxic aromatic amines. Due to low operating costs, the search for sorbents capable of selective removal of dyes is a challenge for many groups of scientists from around the world. The isotherm parameters of the Freundlich, Langmuir and Temkin models as well as the sorption rate constants based on the pseudo-first, pseudo-second and Elovich kinetic models were calculated. Regeneration of Adsorbsia As500 was performed. The column studies were carried out order to determine the breakthrough capacities.

\section{Experimental}

Adsorbsia As500 (As500) is a granular titanium oxide designed by Dow Chemicals (USA). The adsorbent characteristics is presented in Fig. 1. The stock solutions of such textile dyes such as C.I. Acid Red 18 (Boruta-Zachem, Poland), C.I. Direct Yellow 50 (Boruta-Zachem, Poland) and C.I. Reactive Blue 21 (Everlight Chemical Industrial Co., Taiwan) was prepared in a $1 \mathrm{~L}$ graduated flask in which a weighed quantity of dye was dissolved in distilled water. The structural formulae of the above-mentioned dyes and their short characteristics are presented in Fig. 1.

\subsection{Static experiments}

Static studies were carried out in conical flasks. $0.5 \mathrm{~g}$ $( \pm 0.0005)$ of Adsorbsia As500 and $50 \mathrm{~mL}$ of the dye solution of a strictly defined initial concentration (kinetic studies: $\mathrm{C}_{0}=100,300,500 \mathrm{mg} / \mathrm{L}$ in the case of AR 18 and DY50 or $10,30,50$ and $100 \mathrm{mg} / \mathrm{L}$ in the case of RB21; equilibrium studies: $\mathrm{C}_{0}=10-3500 \mathrm{mg} / \mathrm{L}$ ) were placed in laboratory shaker (Elpin Plus, type 357; Poland). The flasks were mixed at a constant speed $(\mathrm{v}=180 \mathrm{cpm})$ at a constant amplitude $(\mathrm{A}=8)$ at room temperature $(\mathrm{T}=$ ambient $)$ and at specific time intervals ( $\mathrm{t}$ ) (kinetic studies: $\mathrm{t}=1-240 \mathrm{~min}$.; equilibrium studies: $\mathrm{t}=24 \mathrm{~h}$ ). Then the adsorbent was separated from the aqueous solutions by filtration. The concentrations of AR18, DY50 and RB21 in the aqueous phase were determined using a UV-Vis spectrophotometer Cary 60 (Agilent, USA) at the maximum wavelengths of $507 \mathrm{~nm}, 396 \mathrm{~nm}$ and $663 \mathrm{~nm}$, respectively. On the basis of the obtained results, $\mathrm{q}_{\mathrm{t}}$ (the amount of dye adsorbed at time $\mathrm{t}$ ) and $\mathrm{q}_{\mathrm{e}}$ (the amount of dye adsorbed at equilibrium) were calculated using the following formulae $(1,2)$ : 
Fig. 1 Characteristics of the dyes and adsorbent

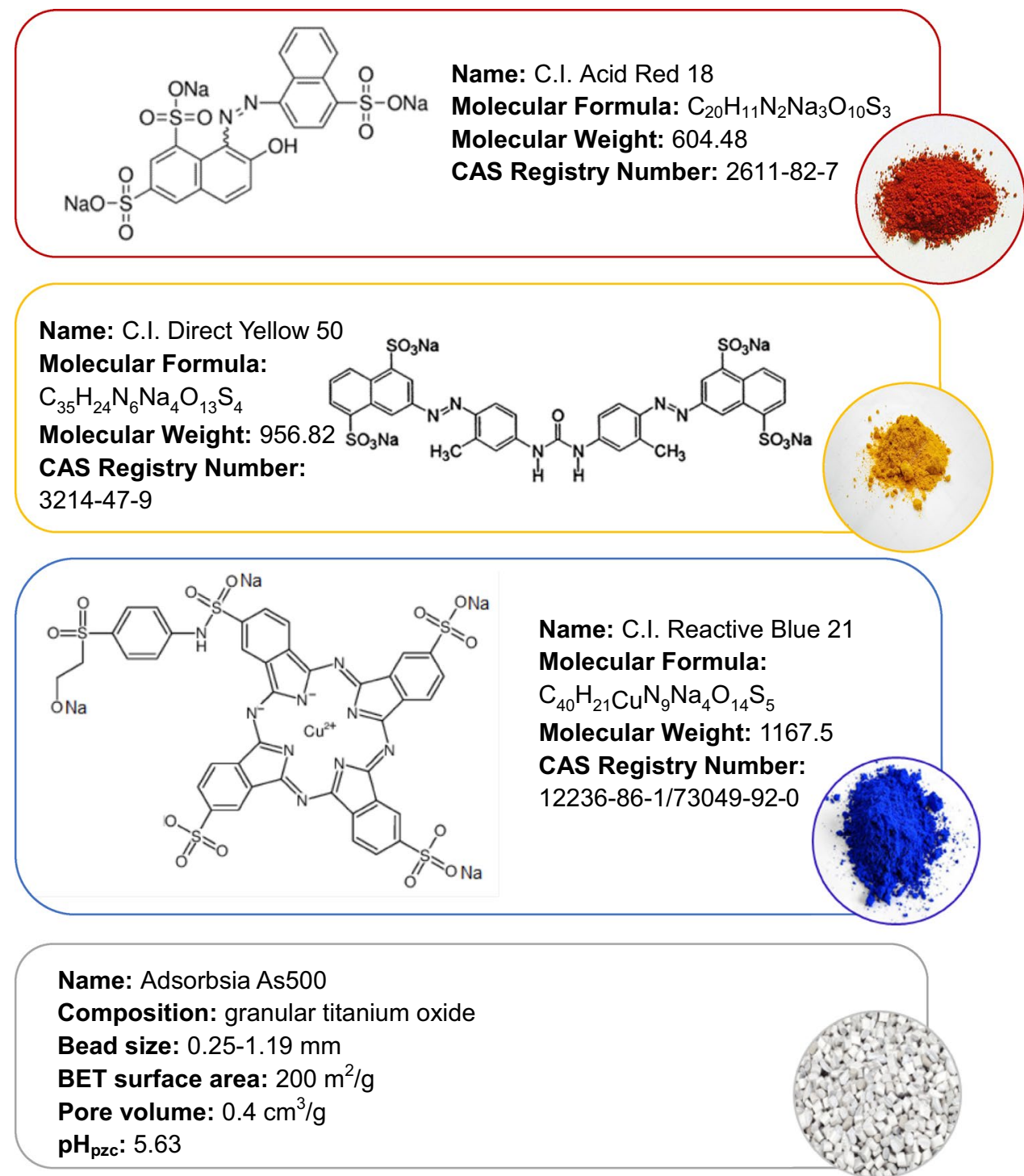

$\mathrm{q}_{\mathrm{t}}=\frac{\left(\mathrm{C}_{0}-\mathrm{C}_{\mathrm{e}}\right)}{\mathrm{m}} \cdot \mathrm{V}$

$\mathrm{q}_{\mathrm{e}}=\frac{\left(\mathrm{C}_{0}-\mathrm{C}_{\mathrm{e}}\right)}{\mathrm{m}} \cdot \mathrm{V}$

where: $\mathrm{C}_{0}$ - the initial concentration of the dye AR18, DY50 or RB21 (mg/L), $\mathrm{C}_{\mathrm{t}}$ - the concentration of the dye after the sorption time $\mathrm{t}(\mathrm{mg} / \mathrm{L}), \mathrm{C}_{\mathrm{e}}$ - the concentration of the dye in equilibrium state $(\mathrm{mg} / \mathrm{L}), \mathrm{V}$ - the volume of the solution (L), $\mathrm{m}$ - the adsorbent mass $(\mathrm{g})$.

The next step was the elution test. $50 \mathrm{~mL}$ of water, $50 \% \mathrm{v} / \mathrm{v}$ methanol, $0.1 \mathrm{M} \mathrm{NaOH}$ or $0.1 \mathrm{M} \mathrm{HCl}$ was added to the portion of Adsorbsia As500 (0.5 g) with retained AR18, DY50, RB21 (sorption conditions: $\mathrm{C}_{0}=500 \mathrm{mg} / \mathrm{L}$ for AR18 and DY 50 and $\mathrm{C}_{0}=50 \mathrm{mg} / \mathrm{L}$ for $\mathrm{RB} 21, \mathrm{~T}=$ ambient, $\mathrm{t}=15 \mathrm{~min}$ ). The suspension was mixed for $1 \mathrm{~h}$ at a constant speed $(\mathrm{v}=180 \mathrm{cpm})$ and amplitude $(\mathrm{A}=8)$. Then the adsorbent was separated from the aqueous solutions by filtration and the dye concentration was measured using spectrophotometer. The degree of dye elution (\%D) was calculated by mass balance.

\subsection{Dynamic experiments}

In the dynamic procedure the glass columns filled with $10 \mathrm{~mL}$ of Adsorbsia As500 was used. The dyes solutions of the initial concentrations of $100 \mathrm{mg} / \mathrm{L}, 300 \mathrm{mg} / \mathrm{L}$ and $500 \mathrm{mg} / \mathrm{L}$ of AR 18 and DY 50 or $10 \mathrm{mg} / \mathrm{L}, 30 \mathrm{mg} / \mathrm{L}, 50 \mathrm{mg} / \mathrm{L}, 100 \mathrm{mg} / \mathrm{L}$ of RB21 were passed through the bed at the flow rate $(0.6 \mathrm{~mL} /$ min). Effluents were collected in fractions and subjected to the 
spectrophotometric analysis. The working capacities $\left(\mathrm{q}_{\mathrm{r}}\right)$ were calculated from Eq. (3):

$\mathrm{q}_{\mathrm{r}}=\frac{\mathrm{C}_{0} \cdot \mathrm{V}_{\mathrm{p}}}{\mathrm{V}_{\mathrm{b}}}$

where: $\mathrm{C}_{0}$ - the initial concentration of AR18, DY50 or $\mathrm{RB} 21(\mathrm{mg} / \mathrm{L}), \mathrm{V}_{\mathrm{p}}$ - the effluent volume to the breakthrough point of column (L), $\mathrm{V}_{\mathrm{b}}$ - the volume of swollen adsorbent $(\mathrm{L})$.

\section{Results and discussion}

\subsection{Isotherm studies}

Isotherms determine the balance of adsorbate concentration between the solid phase and liquid phase. Analyzing the course of isotherms can provide quite accurate information on the maximum adsorption capacity. In addition, they are also a source of information regarding the sorbent power under the tested conditions (Srivastava et. al 2007, Hsu et al. 2008). What is more, in each case we can encounter another type of sorption mechanism: physical, chemical, ion exchange or another interaction. Setting such a mechanism is not easy because they can occur simultaneously, having a smaller share in a given process. However, the designation of the dominant mechanism leads to the largest possible efficiency of the sorption process and at the same time facilitates control over it. The analysis of the results obtained in this paper was made based on the following isotherm models: Langmuir, Freundlich and Temkin ones. The characteristics of the models used together with the relevant parameters are presented in Table 1.

Analyzing the obtained results, it can be concluded that AR18 and DY50 adsorption on As500 is in agreement with the Langmuir model rather than Freundlich or Temkin one (Table 2). This is evidenced by high values of determination coefficients $\left(\mathrm{R}^{2} \geq 0.997\right)$. The monolayer capacities $\left(\mathrm{Q}_{0}\right)$ were equal to $24.92 \mathrm{mg} / \mathrm{g}$ and 109.71 for AR 18 and DY50, respectively and they correspond to the obtained experimental data (Fig. 2(a)). In the case of RB21 adsorption on As500 better fitting of the experimental data was obtained using the Freundlich model $\left(\mathrm{R}^{2}=0.973\right)$. This indicates a multilayer coverage of As500 surface by RB21 anions as well as not well-defined adsorption amount and distribution of adsorption heat. This indicates the complex nature of RB21 adsorption (Fig. 2b).

Wawrzkiewicz et al. (2015a, b) carried out the research on the removal of C.I. Acid Orange 7 (AO7), C.I. Direct Blue 71 (DB71) and Reactive Black 5 (RB5) on the mixed silicon and aluminum oxide $\left(\mathrm{SiO}_{2}: \mathrm{Al}_{2} \mathrm{O}_{3}=4 \%: 96 \% \mathrm{w} / \mathrm{w}\right)$. High values of the determination coefficients indicate that the experimental data were also described by the Langmuir model. The monolayer capacities were found to be $41.1 \mathrm{mg} / \mathrm{g}$ for $\mathrm{AO} 7,47.1 \mathrm{mg} / \mathrm{g}$ for RB5 and $49.2 \mathrm{mg} / \mathrm{g}$ for DB71. The research results obtained by the authors confirmed the high affinity of $\mathrm{SiO}_{2}-\mathrm{Al}_{2} \mathrm{O}_{3}$ for the direct dye. Sorption of the above-mentioned dyes depends on the type and concentration of the surface groups of SA96. The mixed silicon and titanium oxide $\left(\mathrm{SiO}_{2}: \mathrm{TiO}_{2}=80 \%: 20 \%\right.$ w/w, ST20) was used to remove C.I. Acid Yellow 219 (AY219) from the coloured solutions. Comparing the
Table 1 Characteristics of the isotherm equations

\begin{tabular}{|c|c|c|c|c|}
\hline Isotherm & Linear form & Graph & Parameters & Eq. nos \\
\hline Langmuir & $\frac{C_{e}}{q_{e}}=\frac{1}{Q_{o} b}+\frac{C_{e}}{Q_{o}}$ & $\mathrm{C}_{\mathrm{e}} / \mathrm{q}_{\mathrm{e}}$ vs. $\mathrm{C}_{\mathrm{e}}$ & $\begin{array}{l}\mathrm{Q}_{\mathrm{o}}=1 / \text { slope } \\
\mathrm{b}=\text { slope/intercept }\end{array}$ & (4) \\
\hline Freundlich & $\log q_{e}=\log k_{F}+\frac{1}{n} \log C_{e}$ & $\log \mathrm{q}_{\mathrm{e}}$ vs. $\log \mathrm{C}_{\mathrm{e}}$ & $\begin{array}{l}1 / \mathrm{n}=\text { slope } \\
\mathrm{k}_{\mathrm{F}}=10^{\text {intercept }}\end{array}$ & (5) \\
\hline Temkin & $q_{e}=\left(\frac{R T}{b_{T}}\right) \ln A+\left(\frac{R T}{b_{T}}\right) \ln C_{e}$ & $\mathrm{q}_{\mathrm{e}}$ vs. $\ln \mathrm{C}_{\mathrm{e}}$ & $\begin{array}{l}\mathrm{b}_{\mathrm{T}}=\mathrm{RT} / \text { slope } \\
\mathrm{A}=\exp (\text { intercept } / \text { slope })\end{array}$ & (6) \\
\hline
\end{tabular}

where: $q_{e}$, the amount of dye adsorbed per unit mass of As500 (mg/g); $C_{\mathrm{e}}$, the equilibrium concentration of solution $(\mathrm{mg} / \mathrm{L}) ; Q_{0}$, the monolayer adsorption capacity $(\mathrm{mg} / \mathrm{g}) ; b$, the Langmuir constant (related to the free energy of adsorption) $(\mathrm{L} / \mathrm{mg}) ; k_{F}(\mathrm{mg} / \mathrm{g})$ and $1 / n$, the Freundlich constants connected with adsorption capacity of adsorbent and the surface heterogeneity; respectively; R, the gas constant $(8.314 \mathrm{~J} / \mathrm{mol} \mathrm{K})$; $\mathrm{T}$, the temperature $(\mathrm{K}) ; A(\mathrm{~L} / \mathrm{g})$ and $b_{T}(\mathrm{~J} / \mathrm{mol})$, the Temkin constants; slope, direction factor of the respective graph; intercept, intersection of the graph with the $\mathrm{y}$ axis
Table 2 Comparison of the isotherm parameters for C.I. Acid Red 18, C.I. Direct Yellow 50 and C.I. Reactive Blue 21 sorption on Adsorbsia As500

\begin{tabular}{|c|c|c|c|c|c|c|c|c|c|}
\hline \multirow[t]{2}{*}{ Dye } & \multicolumn{3}{|c|}{ Langmuir } & \multicolumn{3}{|c|}{ Freundlich } & \multicolumn{3}{|c|}{ Temkin } \\
\hline & $\mathrm{R}^{2}$ & $\mathrm{Q}_{0}(\mathrm{mg} / \mathrm{g})$ & $\mathrm{b}(\mathrm{L} / \mathrm{mg})$ & $\mathrm{R}^{2}$ & $\mathrm{n}$ & $\mathrm{k}_{\mathrm{F}}(\mathrm{mg} / \mathrm{g})$ & $\mathrm{R}^{2}$ & A (L/g) & $\mathrm{b}_{\mathrm{T}}(\mathrm{J} / \mathrm{mol})$ \\
\hline AR18 & 0.999 & 24.92 & 0.002 & 0.942 & 2.94 & 1.48 & 0.943 & 0.081 & 632.8 \\
\hline DY50 & 0.997 & 109.71 & 0.005 & 0.915 & 4.11 & 16.18 & 0.607 & 0.332 & 160.8 \\
\hline RB21 & 0.640 & 43.29 & 0.023 & 0.973 & 1.86 & 0.83 & 0.934 & 0.491 & 386.2 \\
\hline
\end{tabular}


(a)

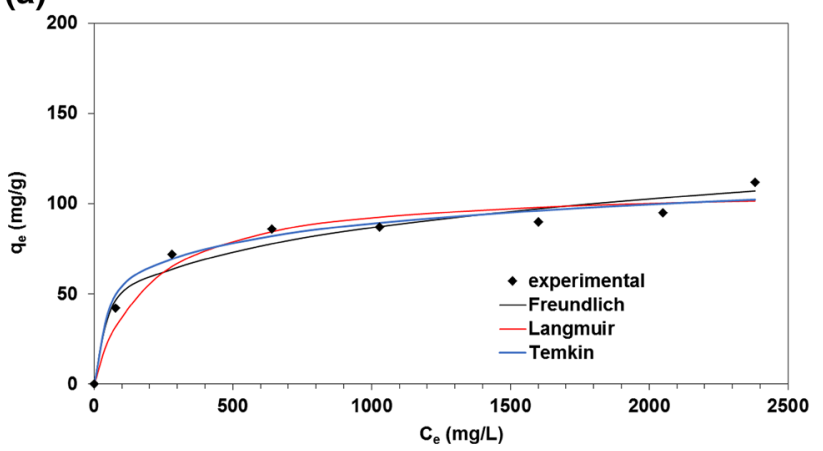

(b)

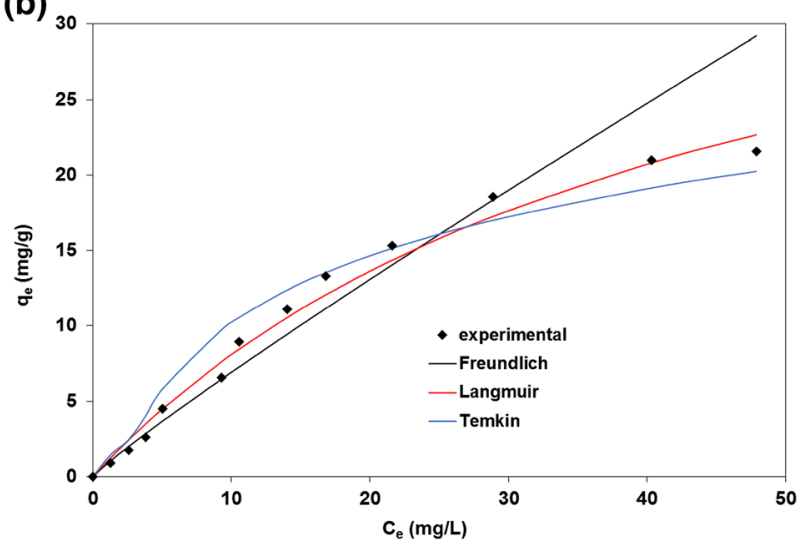

Fig. 2 Equilibrium adsorption of a C.I. Direct Yellow 50 and b C.I. Reactive Blue 21 by Adsorbsia As500 values of the determination coefficients $\left(\mathrm{R}^{2}\right)$, it can be concluded that there was obtained better adjustment of the experimental data to the Freundlich model as evidenced by a higher value of the determination coefficient $\left(\mathrm{R}^{2}=0.929\right)$ rather than to the Langmuir $\left(\mathrm{R}^{2}=0.920\right)$ or Temkin $\left(\mathrm{R}^{2}=0.848\right)$ model (Wiśniewska et al. 2018).

Comparing the obtained data with the literature reports it can be concluded that the amount of dye removed from the solution depends on its type (size and structure, number of chromophores and auxochromes). Taking into consideration adsorption of the dyes on the surface of As500 in relation to kinetic and equilibrium parameters it can be stated that it is a complex process. Mechanism of AR18, DY50 and RB21 adsorption is based on the electrostatic interactions between protonated hydroxyl groups $\left(-\mathrm{OH}_{2}{ }^{+}\right)$ of As500 in acidic solution and sulphonic groups $\left(\mathrm{SO}_{3}-\right)$ of the dyes. The efficiency of dyes adsorption is also determined by the availability of sulphonic groups present in the dyes' structure. Formation of the weak hydrogen bonds and ion-exchange mechanism cannot be excluded, too. Figure 3 presents assumed mechanism of interactions between acid, direct and reactive dyes and As500.

Similar conclusions were reported by Siwińska-Stefańska et al. (2012, 2017). Those authors stated that C.I. Food Yellow 4, C.I. Food Blue 5:2 and C.I. Food Red 9 as well as C.I. Food Black 1, C.I. Food Brown 3 and C.I. Food Green 4 adsorption on $\mathrm{TiO}_{2}-\mathrm{SiO}_{2}$ and $\mathrm{TiO}_{2}$ oxides is based on electrostatic interactions between the negatively charged

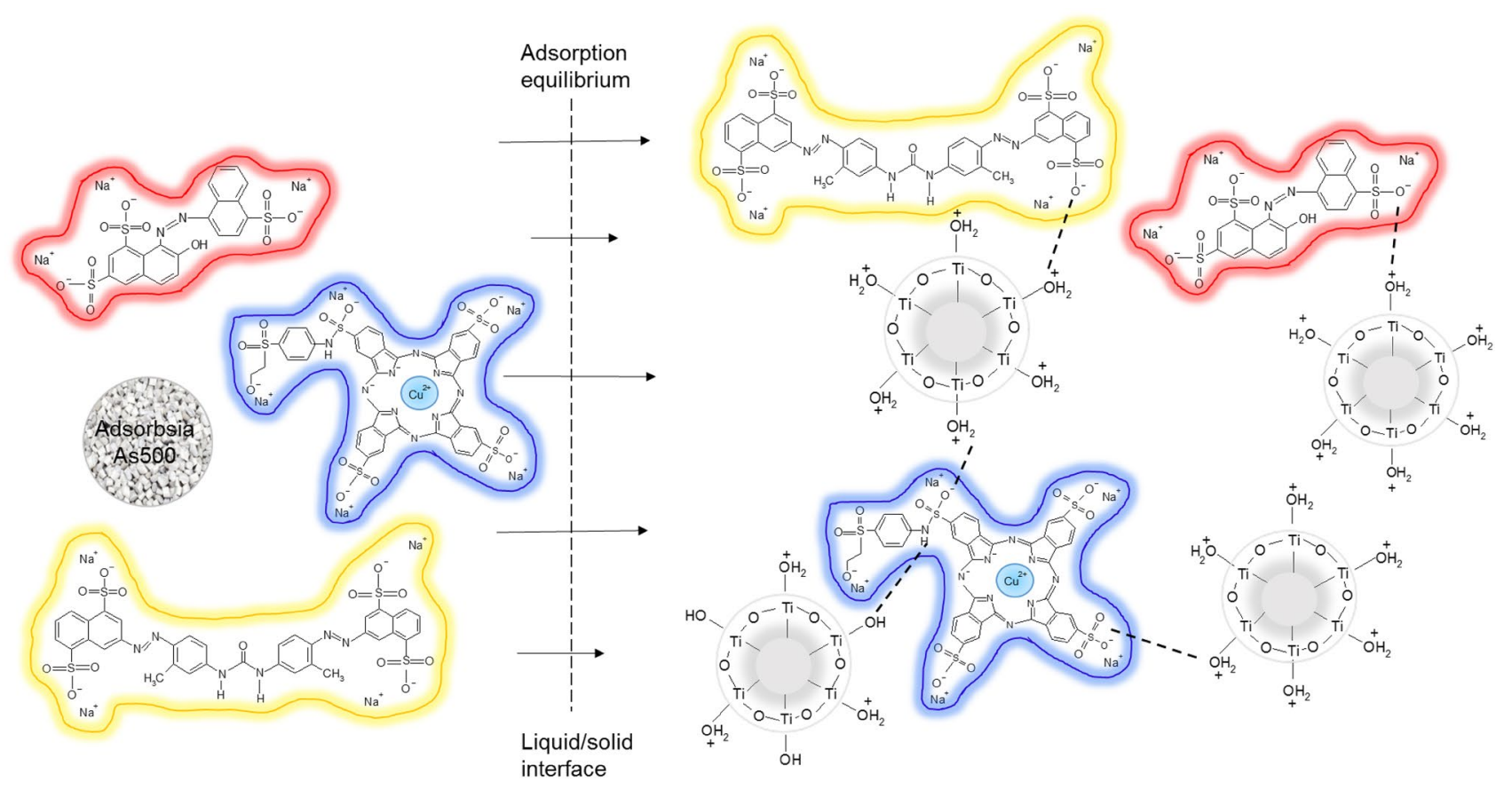

Fig. 3 Proposed mechanism of interactions between AR18, DY50 and RB21 and As500 in acidic medium 
sulphonic groups in the dyes and the positive charge of $\mathrm{TiO}_{2}$ surface in acidic $\mathrm{pH}$.

\subsection{Kinetic studies}

Influence of phase contact time on AR18, DY50 and RB21 sorption on As500 was examined changing the initial dye concentration in the range $100-500 \mathrm{mg} / \mathrm{L}$ of AR 18 and DY50 or $10-100 \mathrm{mg} / \mathrm{L}$ of RB21 at room temperature (Fig. 4). The equilibrium state of sorption process in the AR18-As500 system was determined after approximately 180 min for all dye solutions. In the solutions containing $10 \mathrm{mg} / \mathrm{L}$ and $20 \mathrm{mg} / \mathrm{L}$ of RB21 the equilibrium occurred after $60 \mathrm{~min}$ whereas for the dye concentration of $50 \mathrm{mg} / \mathrm{L}$ and $100 \mathrm{mg} / \mathrm{L}$ this time was longer being $200 \mathrm{~min}$. DY50 sorption equilibrium in the $100-500 \mathrm{mg} / \mathrm{L}$ systems was the slowest and was achieved after $240 \mathrm{~min}$. Rapid adsorption of the dye in the initial stage of sorption may result from the high concentration gradient between the dye in the aqueous solution and the Adsorbsia As500 due to a large number of free adsorption sites.

In order to analyze the sorption process in a more detailed way, kinetic parameters of sorption were calculated. The interpretation of sorption mechanisms has been done using the following kinetic models:

- Pseudo-first order Langergren (PFO) (Lagergren 1898)

$$
\log \left(q_{e}-q_{t}\right)=\log \left(q_{e}\right)-\frac{k_{1}}{2,303} t
$$

- Pseudo-second model (PSO) (Ho and McKay 1999)

$$
\frac{\mathrm{t}}{\mathrm{q}_{\mathrm{t}}}=\frac{1}{\mathrm{kq}_{\mathrm{e}}^{2}}+\frac{1}{\mathrm{q}_{\mathrm{e}}} \mathrm{t}
$$

- Elovich (Low 1960)

$$
\mathrm{q}_{\mathrm{t}}=\frac{1}{\beta} \ln \mathrm{t}+\frac{1}{\beta} \ln \alpha \beta
$$

where: $\mathrm{q}_{\mathrm{e}}, \mathrm{q}_{\mathrm{t}}$-the amounts of dyes adsorbed at equilibrium and time $\mathrm{t}$, respectively $(\mathrm{mg} / \mathrm{g}), \mathrm{k}_{1}$ - the adsorption rate constant of the pseudo-first order kinetic model (1/ $\mathrm{min}$ ), $\mathrm{t}$ - the time ( $\mathrm{min}), \mathrm{k}_{2}$ - the adsorption rate constant of the pseudo-second order kinetic model ( $\mathrm{g} / \mathrm{mg} \mathrm{min}), \alpha$ - the initial adsorption rate $(\mathrm{mg} / \mathrm{g} \mathrm{min}), \beta$ - the desorption constant $(\mathrm{g} / \mathrm{mg})$.

Table 3 compares the kinetic parameters calculated from the PFO, PSO and Elovich equations. Based on calculated parameters, it can be concluded that the best fit of experimental data $\left(\mathrm{q}_{\mathrm{e}, \text { exp }}\right)$ was obtained using the pseudo-second (a)

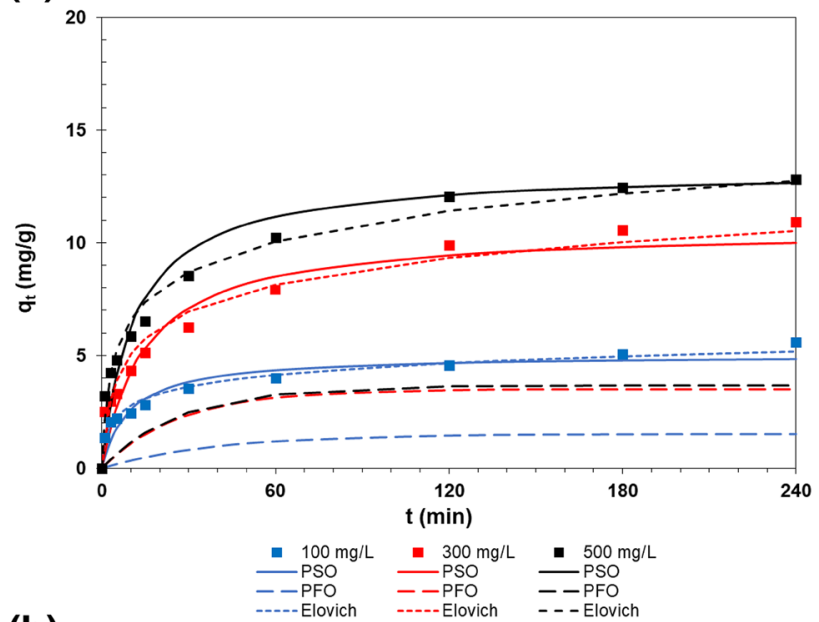

(b)

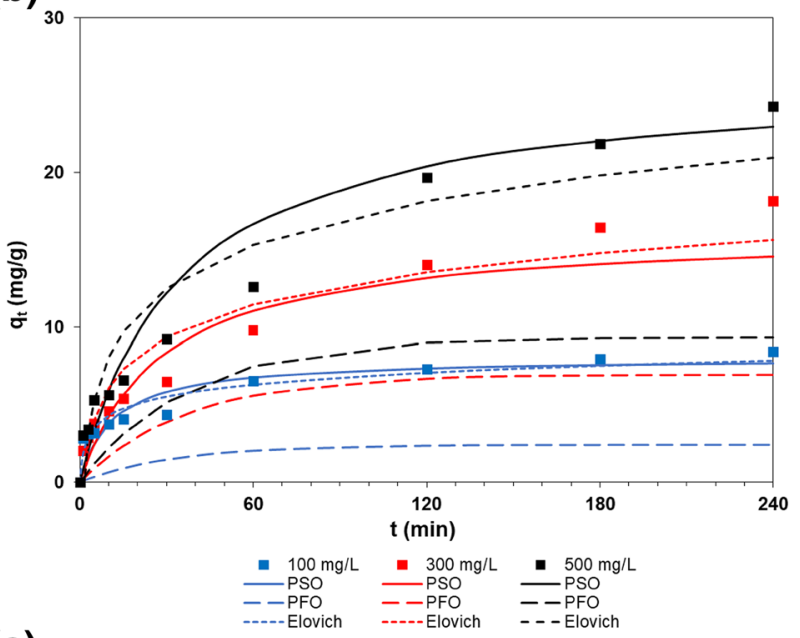

(c)

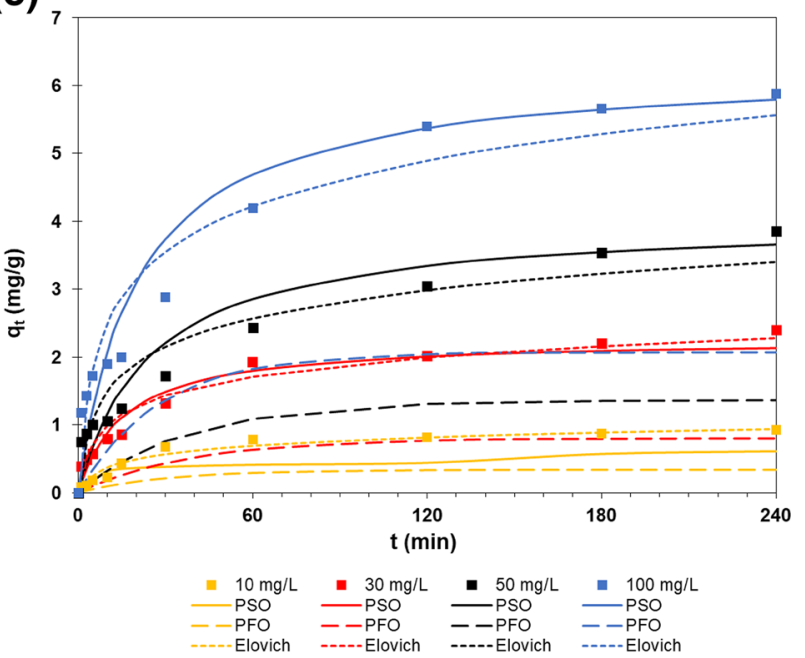

Fig. 4 The effect of phase contact time and initial concentration of a C.I. Acid Red 18, b C.I. Direct Yellow 50 and c C.I. Reactive Blue 21 on the amount of dye adsorbed by Adsorbsia As500 
Table 3 Kinetic parameters for adsorption of C.I. Acid Red 18, C.I. Direct Yellow 50 and C.I. Reactive Blue 21 on Adsorbsia As500 using the pseudo-first order, pseudo-second order and Elovich equations

\begin{tabular}{|c|c|c|c|c|c|c|c|c|c|c|c|}
\hline \multirow[t]{2}{*}{ Dye } & \multirow[t]{2}{*}{$\mathrm{C}_{0}(\mathrm{mg} / \mathrm{L})$} & \multirow[t]{2}{*}{$\mathrm{q}_{\mathrm{e}, \exp }(\mathrm{mg} / \mathrm{g})$} & \multicolumn{3}{|l|}{ PFO } & \multicolumn{3}{|l|}{ PSO } & \multicolumn{3}{|l|}{ Elovich } \\
\hline & & & $\mathrm{q}_{\mathrm{e}}(\mathrm{mg} / \mathrm{g})$ & $\mathrm{k}_{1}(1 / \min )$ & $\mathrm{R}^{2}$ & $\mathrm{q}_{\mathrm{e}}(\mathrm{mg} / \mathrm{g})$ & $\mathrm{k}_{2}(\mathrm{~g} / \mathrm{mg} \min )$ & $\mathrm{R}^{2}$ & $\alpha(\mathrm{mg} / \mathrm{g} \min )$ & $\beta(\mathrm{g} / \mathrm{mg})$ & $\mathrm{R}^{2}$ \\
\hline \multirow[t]{3}{*}{ AR18 } & 100 & 5.6 & 3.5 & 0.011 & 0.923 & 5.0 & 0.021 & 0.995 & 3.0 & 1.32 & 0.978 \\
\hline & 300 & 11.0 & 8.1 & 0.016 & 0.967 & 10.6 & 0.006 & 0.983 & 3.3 & 0.58 & 0.953 \\
\hline & 500 & 13.0 & 8.4 & 0.016 & 0.981 & 13.2 & 0.007 & 0.997 & 5.7 & 0.51 & 0.973 \\
\hline \multirow[t]{3}{*}{ DY50 } & 100 & 8.5 & 5.5 & 0.013 & 0.963 & 8.1 & 0.011 & 0.992 & 5.3 & 0.89 & 0.899 \\
\hline & 300 & 18.2 & 15.6 & 0.011 & 0.657 & 16.2 & 0.002 & 0.999 & 2.2 & 0.33 & 0.888 \\
\hline & 500 & 24.5 & 21.5 & 0.012 & 0.626 & 26.2 & 0.001 & 0.999 & 2.9 & 0.25 & 0.879 \\
\hline \multirow[t]{4}{*}{ RB21 } & 10 & 1.0 & 0.8 & 0.014 & 0.812 & 0.9 & 0.047 & 0.993 & 0.1 & 5.60 & 0.938 \\
\hline & 30 & 2.4 & 1.8 & 0.013 & 0.920 & 2.3 & 0.028 & 0.993 & 0.5 & 2.45 & 0.939 \\
\hline & 50 & 3.9 & 3.1 & 0.012 & 0.996 & 4.0 & 0.010 & 0.976 & 0.7 & 1.66 & 0.890 \\
\hline & 100 & 5.9 & 4.8 & 0.015 & 0.772 & 6.3 & 0.008 & 0.986 & 1.3 & 1.02 & 0.907 \\
\hline
\end{tabular}

order model (PSO) basically supports chemisorption. This is indicated by the high values of the determination coefficients and $\mathrm{q}_{\mathrm{e}}$ values calculated from the Ho equation which are very close to the $\mathrm{q}_{\mathrm{e}, \mathrm{exp}}$ ones. The fitting results presented in Fig. 3 shows that the Elovich equation was also successfully used to describe second-order kinetics signified the role of chemisorption as probably one of the basic rate limiting adsorption step. The pseudo-firs order model yielded relatively low $\mathrm{R}^{2}$ compared with PSO and Elovich equations hence its applicability was dismissed in description of sorption kinetics of AR18, DY50 and RB21 dyes on Adsorbsia As500.

Wiśniewska et al. (2018) analyzing the sorption properties of C.I. Acid Yellow 219 on the silica-titania mixed oxide also confirmed that the best fit of the experimental data.

$\left(\mathrm{q}_{\mathrm{e}, \exp }=9.7 \mathrm{mg} / \mathrm{g}\right)$ was obtained using the PSO model as indicated by high $\mathrm{R}^{2}$ values $\left(\mathrm{R}^{2}=0.999, \mathrm{q}_{\mathrm{e}}=9.69 \mathrm{mg} / \mathrm{g}\right)$.

The research carried out by Arshadi et al. (2013) and Yahyaei et. al. (2012) also confirmed the use of the PSO model for the description of Methyl Orange sorption kinetics on the mixed $\mathrm{SiO}_{2}-\mathrm{Al}_{2} \mathrm{O}_{3}$ oxide. What is more, these results were also confirmed by Banerjee et al. (2014) who removed Methylene Blue in adsorption processes using fly ash composed of aluminum and silicon oxides. Comparing the experimental data with those calculated from the PFO and Elovich models the pseudo-second order model turned out to be the most coherent.

\subsection{Desorption studies}

In the present studies, various desorption solutions were used in the batch mode system in order to find a suitable regeneration agent. The amounts of AR18, DY50 and RB21 eluted by the water from the As500 were of the order $9.2 \%$, $0.8 \%$ and $1.3 \%$, respectively. $50 \% \mathrm{v} / \mathrm{v}$ methanol increase desorption of dyes from titania based adsorbent in all cases as presented in Fig. 5. The degree of AR18 desorbed from As500 was found to be $87.4 \%$ using $0.1 \mathrm{M} \mathrm{NaOH}$. The regenerating agent such as $0.1 \mathrm{M} \mathrm{HCl}$ was ineffective. These results indicate that dyes were retained by the As500 through more than one binding force: electrostatic interaction, hydrogen bonding or ion-exchange. The weaker the interaction of the dye with the adsorbent surface, the easier it is to desorb. The desorption conditions identified here are consistent with the previous observations made by Jesionowski (2012), Siwińska-Stefańska et al. (2012, 2017) and Ciesielczyk et al. (2017).

\subsection{Dyes sorption in the dynamic system}

For a more accurate and more thorough analysis of the sorption data, the tests were also carried out in a column system. Sorption processes conducted in industrial plants are technological processes under different conditions and the designation of the sorption capacity must be adapted to the specific system. Therefore the dyes sorption in the column mode was conducted by passing AR 18 and DY50

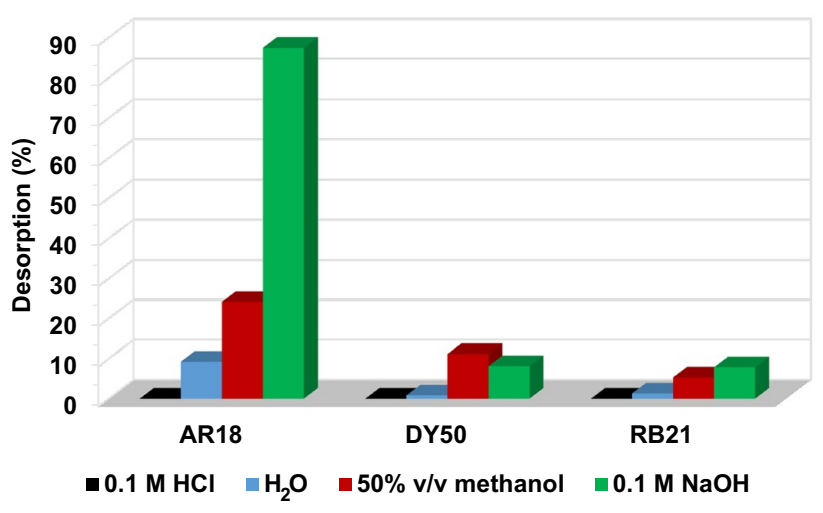

Fig. 5 Degree of dyes elution from As500 


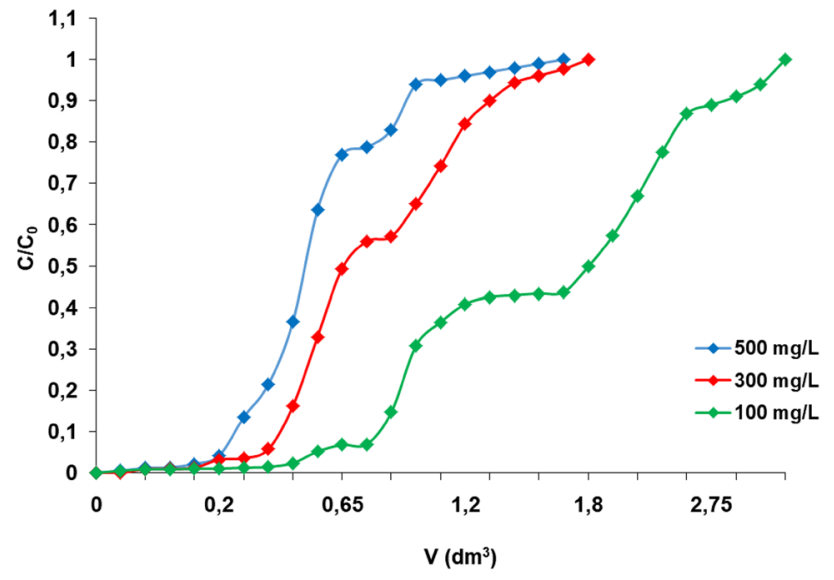

Fig. 6 Breakthrough curves determined in the $100-500 \mathrm{mg} / \mathrm{L}$ DY50 - As500 system

Table 4 Working sorption capacities $\left(\mathrm{q}_{\mathrm{r}}\right)$ for C.I. Acid Red 18, C.I. Direct Yellow 50 and C.I. Reactive Blue 21 retention on the As500 in the systems containing $100-500 \mathrm{mg} / \mathrm{L}$ AR18 and DY50 or $10-100 \mathrm{mg} / \mathrm{L}$ RB21

\begin{tabular}{lll}
\hline Dye & $\mathrm{C}_{0}(\mathrm{mg} / \mathrm{L})$ & $\begin{array}{l}\text { Working } \\
\text { capacity }(\mathrm{mg} / \\
\mathrm{mL})\end{array}$ \\
\hline AR18 & 100 & 1.0 \\
& 300 & 0.9 \\
& 500 & 0.5 \\
DY50 & 100 & 1.5 \\
& 300 & 0.9 \\
RB21 & 500 & 0.5 \\
& 10 & 0.4 \\
& 30 & 0.45 \\
& 50 & 0.55 \\
\hline
\end{tabular}

$\left(\mathrm{C}_{0}=100-500 \mathrm{mg} / \mathrm{L}\right)$ or $\mathrm{RB} 21\left(\mathrm{C}_{0}=10-100 \mathrm{mg} / \mathrm{L}\right)$ solutions through As500 bed. Base on the breakthrough curves (Fig. 6), the working ion exchange capacities were calculated (Table 4). It appears that As500 was more effective for sorption of DY50 than for AR18 or RB21 in the column system. Increasing initial concentration of DY 50 and AR 18 in the system from 100 to $500 \mathrm{mg} / \mathrm{L}$ decrease of the working ion exchange capacities was observe. A reverse relationship was observed in the RB21-As500 system. This is due to the slight adsorption of the RB21 dye. On the basis of the obtained values, the affinity series can be presented as follows: DY50 > AR18 > RB21.

\section{Conclusions}

The paper discusses the adsorption of textile dyes such as AR18, DY50 and RB21 on the granular titanium dioxide (Adsorbsia As500). The studies showed that the highest sorption capacity was obtained for DY50 $(109.71 \mathrm{mg} / \mathrm{g})$ in comparison to the others dyes. Kinetic studies proved that the time needed to achieve the state of equilibrium was the longest in the system containing DY50 and was found to be more than 240 min while for AR18 and RB21 it was $180 \mathrm{~min}$ and $200 \mathrm{~min}$, respectively. Comparing the values of the kinetic parameters obtained using the PSO, PFO and Elovich equations, it can be concluded that the experimental data fits to the PSO model. The dyes desorption from As500 phase can be performed with the highest efficiency using $0.1 \mathrm{M} \mathrm{NaOH}$; lower elution was obtained using $50 \% \mathrm{v} / \mathrm{v}$ methanol. The dye retention mechanism is largely due to the electrostatic interaction of the anionic form of the dye with a positively charged surface of titanium oxide in the acidic solution.

The results obtained in the present study show that titanium oxide (Adsorbsia As500) can be an effective sorbent, especially for direct dyes in the processes of wastewaters and aqueous solutions treatment. Considering the economic aspect of the adsorbate, it is characterized by low production cost, fast kinetics and quite high adsorption capacity.

Open Access This article is distributed under the terms of the Creative Commons Attribution 4.0 International License (http://creativeco mmons.org/licenses/by/4.0/), which permits unrestricted use, distribution, and reproduction in any medium, provided you give appropriate credit to the original author(s) and the source, provide a link to the Creative Commons license, and indicate if changes were made.

\section{References}

Andrzejewska, A., Krysztafkiewicz, A., Jesionowski, T.: Adsorption of organic dyes on the aminosilane modified $\mathrm{TiO}_{2}$ surface. Dyes Pigments 62, 121-130 (2004)

Anielak, A.M.: Chemiczne i fizykochemiczne oczyszczanie ścieków. PWN (2000)

Arshadi, A., Vahid, F.S., Salvacion, J.W.L., Soleymanzadeh, M.: A practical organometallic decorated nano-size $\mathrm{SiO}_{2}-\mathrm{Al}_{2} \mathrm{O}_{3}$ mixedoxides for methyl orange removal from aqueous solution. Appl. Surf. Sci. 280, 726-736 (2013)

Banerjee, S., Sharma, G.C., Chattopadhyaya, M.C., Sharma, Y.C.: Kinetic and equilibrium modeling for the adsorptive removal of methylene blue from aqueous solutions on of activated fly ash (AFSH). J. Environ. Chem. Eng. J. 2, 1870-1880 (2014)

Cha, Ch-J., Doerge, D.R., Cerniglia, C.E.: Biotransformation of Malachite Green by the fungus Cunninghamella elegans. Appl. Environ. Microb. 67, 4358-4360 (2001)

Chandrasekha, S., Pramad, P.N.: Rice husk ash as an adsorbent for methylene blue - effect of ashing temperature. Adsorption. 12, 27-43 (2006) 
Ciesielczyk, F., Bartczak, P., Zdarta, J., Jesionowski, T.: Active MgO$\mathrm{SiO}_{2}$ hybrid material for organic dye removal: a mechanism and interaction study of the adsorption of C.I. Acid Blue 29 and C.I. Basic Blue 9. J. Environ. Manage. 204, 123-135 (2017)

Derudi, M., Venturini, G., Lombardi, G., Nano, G., Rota, R.: Biodegradation combined with ozone for the remediation of contaminated soils. Eur. J. Soil Biol. 43, 297-303 (2007)

Diouri, K., Chaqroune, A., Kherbeche, A., Miyah, Y., Lahrichi, A.: Kinetics of Direct Yellow 50 Dye Adsorption onto Marble Powder Sorbents. International Journal of Innovative Research in Science, Engineering and Technology. 3, 16626-16637 (2014)

Erdem, B., Erdem, M., Ozcan, A.S.: Adsorption of Reactive Black 5 onto quaternized 2-dimethylaminoethyl methacrylate based polymer/clay nanocomposites. Adsorption. 22, 767-776 (2016)

Ferraro, F.: Dye removal by low cost adsorbents: Hazelnut shells in comparison with wood sawdust. J. Hazard Material 142, 144-152 (2007)

Ho, Y.S., McKay, G.: Pseudo-second order model for sorption processes. Process Biochem. 34, 451-465 (1999)

Holme, I.: Ecological aspects of color Chemistry. In: Griffiths, J. (ed.) Developments in the Chemistry and Technology of Organic Dyes, pp. 111-128. Society for Chemical Industry, Oxford (1984)

Hsu, T.-C., Yu, C.-C., Yeh, C.-M.: Adsorption of $\mathrm{Cu}^{2+}$ from water using raw and modified coal fly ashes. Fuel. 87, 1355-1359 (2008)

Jafari, Sh, Zhao, F., Zhao, D., Lahtinen, M., Bhatnagar, A., Sillanpää, M.: A comparative study for the removal of methylene blue dye by $\mathrm{N}$ and $\mathrm{S}$ modified $\mathrm{TiO}_{2}$ adsorbents. J. Mol. Liq. 207, 90-98 (2015)

Jafari, Sh, Yahyaei, B., Kusiak-Nejman, E., Sillanpää, M.: The influence of carbonization temperature on the modification of $\mathrm{TiO}_{2}$ in the removal of methyl orange from aqueous solution by adsorption. Desal. Water Treat. 57, 18825-18835 (2016)

Jesionowski, T.: Synthesis of organic-inorganic hybrids via adsorption of dye on an aminosilane-functionalised silica surface. Dyes Pigments 55, 133-141 (2002)

Khan, T.A., Singh, V.V., Kumar, D.: Removal of some basic dyes from artificial textile wastewater by adsorption on Akash Kinari coal. J. Sci. Ind. Res. 63, 355-364 (2004)

Khodaeer, E.A.: Removal of Direct 50 Dyes from Aqueous Solution Using Natural Clay and Organoclay Adsorbents. Baghdad Science Journal. 12, 157-167 (2015)

Khosravi, I., Eftekhar, M.: $\mathrm{Na}_{0.5} \mathrm{Li}_{0.5} \mathrm{CoO}_{2}$ nanopowders: Facile synthesis, characterization and their application for the removal of methylene blue dye from aqueous solution. Adv. Powder Technol. 25, 1721-1727 (2014)

Lagergren, S.: About the theory of so-called adsorption of soluble substances. Kungliga Svenska Vetensk Handl. 24, 1-39 (1898)

Low, M.D.: Kinetics of chemisorption of gases on solids. Chem. Rev. 60, 267-312 (1960)

Mahapatra, A., Mishra, B.G., Hota, G.: Adsorptive removal of Congo red dye from wastewater by mixed iron oxide-alumina nanocomposites. Ceram. Int. 39, 5443-5451 (2013a)

Mahapatra, A., Mishra, B.G., Hota, G.: Electrospun $\mathrm{Fe}_{2} \mathrm{O}_{3}-\mathrm{Al}_{2} \mathrm{O}_{3}$ nanocomposite fibers as efficient adsorbent for removal of heavy metal ions from aqueous solution. J. Hazard. Mater. 258-259, 116-123 (2013b)

Majewska-Nowak, K.: Usuwanie barwników ze ścieków przemysłowych. Ochr. Sr. 488, 17-22 (1986)

Mikhaylov, V.I., Maslennikova, T.P., Ugolkova, V.L., Krivoshapkin, P.V.: Hydrothermal synthesis, characterization and sorption properties of $\mathrm{Al} / \mathrm{Fe}$ oxide-oxyhydroxide composite powders. Adv. Powder Technol. 27, 756-764 (2016)

Mittal, A., Kurup, L., Mittal, J.: Freundlich and Langmuir Adsorption Isotherms and Kinetics for the Removal of Tartrazine from Aqueous Solutions Using Hen Feathers. J. Hazard Material. 146, 243-248 (2007)
Mo, J.H., Lee, Y.H., Kim, J., Jeong, J.Y., Jegal, J.: Treatment of dye aqueous solutions using nanofiltration polyamide composite membranes for the dye wastewater reuse. Dyes Pigm. 76, 429-434 (2008)

Mohammadi, A., Karimi, A.A.: Methylene blue removal using surfacemodified $\mathrm{TiO}_{2}$ nanoparticles: A comparative study on adsorption and photocatalytic degradation. J. Water Environ. Nanotechnol. 2, 118-128 (2017)

Momenzadeha, H., Tehrani-Baghab, A.R., Khosravia, A., Gharanjigc, K., Holmbergd, K.: Reactive dye removal from wastewater using a chitosan nanodispersion. Desalination 271, 225-230 (2011)

Namasivayam, C., Prabha, D., Kumutha, M.: Removal of direct red and acid brilliant blue by adsorption on to banana pith. Biores. Technol. 64, 77-79 (1998)

Pereira, M.F.R., Soares, S.F., Orfao, J.J.M., Figueiredo, J.L.: Adsorption of dyes on activated carbons: influence of surface chemical groups. Carbon. 41, 811-821 (2003)

Przybylska, A., Siwińska-Stefańska, K., Ciesielczyk, F., Jesionowski, T.: Adsorption of C.I. Basic Blue 9 onto $\mathrm{TiO}_{2}-\mathrm{SiO}_{2}$ inorganic support. Physicochem. Probl. Miner. Process. 48, 103-112 (2012)

Robinson, T., McMullan, G., Marchant, R., Nigam, P.: Remediation of dyes in textile effluent: a critical review on current treatment technologies with a proposed alternative. Bioresource Technol. 77, 247-255 (2001)

Ruey-Shin, J., Feng-Chin, W., Ru-Ling, T.: Mechanism of Adsorption of Dyes and Phenols from Water Using Activated Carbons Prepared from Plum Kernels. J. Coloid Interface Sci. 227, 437-444 (2000)

Salleh, M.A.M., Mahmoud, D.K., Karim, W.A., Idris, A.: Cationic and Anionic Dye Adsorption by Agricultural Solid Wastes: A Comprehensive Review. Desalination. 280, 1-13 (2011)

Siwińska-Stefańska, K., Nowacka, M., Kołodziejczak-Radzimska, A., Jesionowski, T.: Preparation of hybrid pigments via adsorption of selected food dyes onto inorganic oxides based on anatase titanium dioxide. Dyes Pigments 94, 338-348 (2012)

Siwińska-Stefańska, K., Szwarc-Rzepka, K., Piasecki, A., Jesionowski, T.: Nano- $\mathrm{TiO}_{2}-\mathrm{SiO}_{2}$ powder as inorganic support for hybrid pigment preparation. Adv. Powder Technol. 28, 1298-1308 (2017)

Siwińska-Stefańska, K., Fluder, M., Jesionowski, T.: Investigation of amino-grafted $\mathrm{TiO}_{2}$ /reduced graphene oxide hybrids as a novel photocatalyst used for decomposition of selected organic dyes. J. Environ. Manage. 212, 395-404 (2018)

Solecka, M., Ledakowicz, S.: Biologiczne procesy oczyszczania barwnych ścieków włókienniczych. Biotechnologia. 2, 103-105 (2005)

Srivastava, S., Sinha, R., Roy, D.: Toxicological effects of Malachite Green. Aquat. Toxicol. 66, 319-329 (2004)

Srivastava, V.C., Mall, I.D., Mishra, I.M.: Adsorption thermodynamics and isosteric heat of adsorption of toxic metal ions onto bagasse fly ash (BFA) and rice husk ash (RHA). Chem. Eng. J. 132, $267-$ 278 (2007)

Wang, S., Zhu, Z.H.: Effects of acidic treatment of activated carbons on dye adsorption. Dyes Pigm. 75, 306-314 (2007)

Wawrzkiewicz, M., Hubicki, Z.: Equilibrium and kinetic studies on the adsorption of acidic dye by the gel anion exchanger. J. Hazard. Mater. 172, 868-874 (2009)

Wawrzkiewicz, M., Hubicki, Z.: Weak Base Anion Exchanger Amberlite FPA51 as Effective Adsorbent for Acid Blue 74 Removal from Aqueous Medium - Kinetic and Equilibrium Studies. Sep. Sci. Technol. 45, 1076-1083 (2010)

Wawrzkiewicz, M., Nowacka, M., Klapiszewski, Ł, Hubicki, Z.: Treatment of wastewaters containing acid, reactive and direct dyes using aminosilane functionalized silica. Open Chem. 13, 82-95 (2015a)

Wawrzkiewicz, M., Wiśniewska, M., Gun'ko, V.M., Zarko, V.I.: Adsorptive removal of acid, reactive and direct dyes from aqueous 
solutions and wastewater using mixed silica-alumina oxide. Powder Technol. 278, 306-315 (2015b)

Wiśniewska, M., Urban, T., Grządka, E., Zarko, V.I., Gun'ko, V.M.: Comparison of adsorption affinity of polyacrylic acid for surfaces of mixed silica-alumina. Colloid Polym. Sci. 292, 699-705 (2014)

Wiśniewska, M., Wawrzkiewicz, M., Polska-Adach, E., Fijałkowska, G., Goncharuk, O.: Nanosized silica-titanium oxide as a potential adsorbent for C.I. Acid Yellow 219 dye removal from textile baths and wastewaters. Appl.Nanosci. 8, 867-876 (2018)

Wołowicz, A., Wawrzkiewicz, M., Hubicki, Z.: Toxic metal ions and metal-complex dye removal from aqueous solutions using an ion exchanger and titanium dioxide. Fibress Text. East. Eur. 26, 108-114 (2018)

Yahyaei, B., Azizian, S.: Rapid adsorption of anionic dyes by ordered nanoporous alumina. Chem. Eng. J. 209, 589-596 (2012)

Publisher's Note Springer Nature remains neutral with regard to jurisdictional claims in published maps and institutional affiliations. 